\title{
Cultivating our cities
}

\author{
I. M. Madaleno \\ Portuguese Tropical Research Institute, Portugal
}

\begin{abstract}
Greenitude helps to beautify urban environments and is used to improve the urbanites' quality of life. Native trees and medicinal herb species are essential components in Latin American front and backyards. They can be found as hedges and flourishing bushes in gardens, in small vases on terraces and balconies, in vacant urban plots, and in peripheral lots and farms. They constitute a valuable resource for low-income residents and a source of alternative medicine for many. In addition central markets and weekly fairs provide a wide variety of wild species used in treatments for mild or chronic diseases, which are well-known by Latin American citizens. The paper presents a comparative study carried out over the course of a decade in Lima (Peru), Santiago (Chile), Río Cuarto (Argentina), Colonia del Sacramento (Uruguay), Belen and S. Louis (Brazil), Havana (Cuba), San José (Costa Rica) and Mexico City (Mexico). The objectives of the ethno-geographic study are twofold: to report successes in natural resources management at a local level as paradoxes of globalisation and to publicise how cultivated front and backyards contribute to build more resilient urban agglomerations, benefitting both the society and the environment, because traditional healing practices and ethno-botanical knowledge are important legacies for future generations.
\end{abstract}

Keywords: medicinal species, urban agriculture, Latin America.

\section{Introduction}

For over 30 years sustainable cities have been the leading paradigm of urban development [1]. The great recession that began with the subprime crisis in the summer 2007 and provoked the U.S. financial collapse [2] has led to the abandonment of some of the most ambitious sustainable development projects, though [3]. Furthermore, resistance to globalisation is widespread among the general public [2], particularly after the 2010 European financial meltdown, 
while the visible hazards associated to global warming present new challenges for urban planning and development initiatives $[4,5]$.

The planning actions are traditionally expert-led and top-down approaches within large-scale investment programmes [6]. The downturn in the economy and finances of developed nations, however, gave local-scale and innovative sustainable urban development options the opportunity to become noticeable, an emerging bottom-up approach [3]. For years regarded as globalisation paradoxes, community and home gardens were suddenly considered good solutions for poverty, un- and underemployment, in the urban realm. Because composting is frequently adopted and chemicals are rarely used, urban and peri-urban agriculture are now considered beneficial for both developed and developing countries while they increase the resilience of the cities.

\section{Methods}

The city and metropolitan area became spaces of the global, often by-passing the traditional scalar hierarchy centred on the national [7]. This paper presents a comparative study that includes one global city - Mexico City - and five other metropolitan areas that are less impressive, in size as in centrality. They are, however, major capital cities for a state - Belem, the biggest agglomeration in Brazilian Amazonia - or of a country - Lima, Peru; Santiago, Chile; San José, Costa Rica; Habana, Cuba. The Portuguese Tropical Research Institute (IICT) exploration of the green spaces existent inside these six metropolises revealed several similarities that further stimulated our curiosity as to the analysis of smaller bounded urban spaces. Hence, in 2010 and 2011, the joint IICT-UNRC team surveyed home garden owners in the city of the pampas, Río Cuarto, located in Argentina (245,839 inhabitants), then the author conducted research in the river Plate Colonia del Sacramento, Uruguay (15,934 residents), and S. Louis, located in the Northeast of Brazil (1,014,837 residents).

The research objectives were to report a series of natural resources management case-studies, at local level - the soil, the water, the forest - used both for health and food, and to recover Latin-American traditional medicinal knowledge in order to provide evidence of alternative livelihoods. The culturally bounded space promised fertile group discussions because, despite the diversity of ethnic influences, the participants had a common colonisation history. Three types of actors were inquired, using the same questionnaire: 1 . Urban gardeners and farmers; 2. Herb traders and pharmacists devoted to plant retail; 3. Traditional healers, plant therapists and natural medicine doctors. Selected healers, wild species collectors and traders, as urban gardeners, had extra scrutiny, by means of open interviews. In Uruguay, where mate tea consumption is the rule, local consumers were further interviewed about their herbal preferences. Qualitative research included video records and photographs, in line with the sources common to other ethnographic work [8]. Collier and Collier [9] claim that 'photographic data are the closest approximation to primary experience that we can gather'. 
Face-to-face interviewing was, however, the basic source of information used during fourteen years of fieldwork in nine cities and metropolis, in Latin America. Table 1 displays the figures related to the samples gathered, together with the percentage of urban gardeners and peri-urban farmers inquired; with the exception of the littoral desert Peruvian capital city, they constituted the bulk of the informants. The table also gives the number of species collected and photographed during fieldwork, per city, which were later identified with the support of local botanists. Advancing results, over one hundred and forty species common to all or most of the urban agglomerations were observed and therefore it's not advisable to add them in the column.

Table 1: $\quad$ Surveys and species collected in six Latin American metropolis and three cities.

\begin{tabular}{|c|c|c|c|}
\hline Cities and countries & $\begin{array}{c}\text { Semi-structured } \\
\text { Interviews (n) }\end{array}$ & $\begin{array}{c}\text { Urban } \\
\text { gardeners and farmers } \\
(\%)\end{array}$ & $\begin{array}{c}\text { Species with } \\
\text { therapeutic } \\
\text { applications } \\
(\mathrm{n})\end{array}$ \\
\hline Belen, Brazil & 570 & 97.3 & 140 \\
\hline Santiago, Chile & 132 & 84.1 & 70 \\
\hline $\begin{array}{c}\text { Mexico City, } \\
\text { Mexico }\end{array}$ & 100 & 42.0 & 60 \\
\hline $\begin{array}{c}\text { Lima, Peru } \\
\text { Havana, Cuba }\end{array}$ & 34 & 0.0 & 60 \\
\hline $\begin{array}{c}\text { San José, Costa Rica } \\
\text { S. Louis, Brazil }\end{array}$ & 43 & 94.0 & 109 \\
\hline $\begin{array}{c}\text { Río Cuarto, } \\
\text { Argentina }\end{array}$ & 100 & 90.0 & 125 \\
\hline $\begin{array}{c}\text { Colonia del } \\
\text { Sacramento, } \\
\text { Uruguay }\end{array}$ & 50 & 80.0 & 70 \\
\hline \begin{tabular}{c} 
Total or average \\
\hline
\end{tabular} & 1,179 & 48.0 & 560 \\
\hline
\end{tabular}

Source: fieldwork data obtained during the 1998-2011 scientific missions.

\section{Results and discussion}

Smith [10] traces the origins of modern science back to the early seventeenth century and Francis Bacon. His vision of a harmonious balance between "man and nature" was immortalized in the "New Atlantis". In our days, as natural catastrophes become more frequent, in spite of the scientific endeavour and the astonishing modern technological achievements, scientists tend to go back to the early seventeenth century balances. Back to nature is the future. 
In spite of the risks and uncertainty in growing food, such as climate change, bad weather, pest-induced crop losses, a considerable proportion of city residents invest their time and meagre resources in fresh produce [11]. Food is not the only purpose of urban agriculture, as learnt in Brazil $[12,13]$. Urban gardeners grow lettuce together with spices and medicinal herbs, using their front and backyards, peri-urban vacant plots and community gardens. The intercropping of species helps to eradicate undesirable insects and creates micro-climates whilst augmenting moisture and facilitating rainwater permeation. In the home gardens there is seldom mono-cultivation; fruit culture is intertwined with annual plants, and the plot fertilisation is usually organic, both because it's cheaper and for the reason that local food is widely perceived as a healthier choice than the chemically driven food industry available in retail stores [11]. Garden irrigation uses wells or municipal water supply $[14,15]$. Recently, urban agriculture has even developed into a permanent activity in Argentina and Uruguay.

In fact, due to the recent and ongoing economic crisis, thousands of urbanites lost their jobs and looked for ways to feed their households as to mitigate their aches and pains through urban cultivation [16]. The unstable macro-economic situations and natural disasters are disturbances that threaten people's livelihoods, particularly in urban agglomerations. These are good reasons to build resilient cities, meaning, self-reliant and capable urban constructs, able to cope with disastrous events [17]. Fortunately, responses to severe economic crises and natural catastrophes are found in literature. That's the case with Argentina and Uruguay, countries that experienced harsh financial collapse impacts around the turn of the millennium [18-20], and post-Katrina New Orleans, in the United States [21]. The successful attempts to resolve food and health provision in the aftermath of shocks gives hope and urges us to find additional solutions in case it happens again.

During the Argentinean-Uruguayan crisis (2001-2005) millions lost their jobs and found themselves without any way to sustain their families. This led to the introduction of strategies of self-employment and created solidarity networks in which urban agriculture was a productive alternative [18]. Even though after the crisis poverty and unemployment declined, the implementation of governmental programmes intended to cultivate food, medicinal and aromatic herbs using environmentally sustainable techniques continued in Argentina. Examples found in Río Cuarto (Cordoba province) show that the usage of compost tanks and ringworms for fertilisation; the practice of intertwining insect repellent species (lemon grass) with other crops; the production of dried medicinal herbs cultivated in front and backyards, using simple drying devices; were all enduring creations of the Ministry of Agriculture, introduced during the IMF intervention and so far in use among Argentinean urban gardeners [20].

As far as New Orleans is concerned, Bailkey wrote that urban agriculture was not introduced through government renewal policies, but via organisations such as the New Orleans Food and Farm Network (NOFFN), the Mary Queen of Vietnam non-governmental organisation (MQVN) and through the energy of city residents. Reality is before Katrina (2005) the city was already characterised by strong neighbourhood identity. In the autumn of 2008, the NGO Parkway 
Partners managed 29 community gardens across the city. Other entrepreneurial actions were taken by the Urban Farming Coalition in order to strengthen the New Orleans food system and build a healthier urban environment [21].

For a decade now the United Nations has been not only accompanying food production in the cities but also actively promoting it, mainly through RUAF Foundation, the International network of Resource centres on Urban Agriculture and Food security [22]. The aim is to link the urban and agriculture spheres in an increasingly urbanised planet, ravaged by poverty and resources scarcity. By the way, it was within the framework of urban agriculture case-studies that current research began [12]. Following the assessment of the importance of medicinal and aromatic species grown in Brazil and, after that, in Chile [23], the IICT evolved from 'food to the fork' into 'from the garden pot to the tea pot'.

Table 2 displays the preferences gathered during the scientific missions to Latin America, and the pharmacological activities of the plant parts collected and studied found in related literature. Evidence that many medicinal plants are imports is seen in the local names of many of them all over Latin America. In Brazil, novel plants and animals are often named by analogy with more familiar local species [24]. The Portuguese word for Melissa officinalis (Erva-Cidreira) came to refer the native American wild lemon bush (Lippia alba) in Brazil. The endemic Agastache officinalis represents exactly such a case. The Spanish term toronjil, originally naming Melissa officinalis in Europe, later named the local Mexican species through analogy.

Comparing the nine agglomerations, it is stressed that the top ranking species is an eclectic herb, easily consumed in digestive infusions, a mild sedative (seven case-studies) or a strong stimulant (Argentina and Uruguay). These plant species are all small bushes and herbs, grown in home gardens or available in local pharmacies for their recognised therapeutic virtues. Overall, the native species predominate (five in nine case-studies), with the exception of chamomile and the European balm, preferred respectively in Peru, Costa Rica, and Chile.

The profusion and diversity of the Native American species collected during field work is evident in Table 3. Some have ancestral common names, such as the Asian pua (Curcuma longa) or the endemic matua' pua (Polypodium scolopendria) of Chile, which is used against rheumatic pains by Eastern Islanders resident in Santiago. Most species, however, adopted Spanish or Portuguese names, after European plants with the same therapeutic application, as said. That's the case of Justicia pectoralis, a dwarf sedative Cuban herb, named tilo after the European Tilia Europeaea [25]. Another example is Verbena jamaicensis, a Caribbean plant named after the European Verbena officinalis. In order to distinguish them, Cubans call the local species 'silvestre' or then 'morada', when the flower is rosy; 'azul' when it is blue. Several medicinal plants are aromatic. The urbanites tend to name them according to their scent, as is the example of tropical Cymbopogon citratus, a strong analgesic herb: té limon, in Mexico; caña limón, in Cuba, zacate limón, in Costa Rica; capim limão, both in Belem and S. Louis. In Brazil, this herb is also called 'holly', capim santo, as we cannot forget that spirituality mingles with traditional medicinal practices. 
Table 2: $\quad$ Top ranking species from nine cities or metropolitan areas of Latin America.

\begin{tabular}{|c|c|c|}
\hline Metropolitan Areas & Common and scientific names & Pharmacological activities \\
\hline $\begin{array}{l}\text { Central Mexican } \\
\text { Region (Mexico city, } \\
\text { Cuernavaca, Puebla), } \\
\text { Mexico }\end{array}$ & $\begin{array}{c}\text { Toronjil } \\
\text { (Mexican Balm) } \\
\text { Agastache mexicana (kunth) } \\
\text { Linton and Epling } \\
\text { LAMIACEAE }\end{array}$ & $\begin{array}{l}\text { Sedative and antispasmodic } \\
\text { activities }\end{array}$ \\
\hline $\begin{array}{l}\text { Lima (Lima and } \\
\text { Callao), Peru }\end{array}$ & $\begin{array}{c}\text { Manzanilla } \\
\text { (Chamomille) } \\
\text { Matricaria chamomilla } \mathrm{L} . \\
\text { ASTERACEAE }\end{array}$ & $\begin{array}{l}\text { Antibacterial, antifungal and } \\
\text { antispasmodic activities. Anti- } \\
\text { inflammatory and sedative } \\
\text { actions. Digestive, anti- } \\
\text { stressing, stomach aches, anti- } \\
\text { influenza, anti-diarrhoeal and } \\
\text { antibiotic, carminative }\end{array}$ \\
\hline $\begin{array}{l}\text { Metropolitan area of } \\
\text { Santiago, Chile }\end{array}$ & $\begin{array}{l}\text { Melisa or Toronjil } \\
\text { (European Balm) } \\
\text { Melissa officinalis L. } \\
\text { LAMIACEAE }\end{array}$ & $\begin{array}{l}\text { Digestive, antibacterial, } \\
\text { antifungal and antispasmodic } \\
\text { activities. Anti-inflammatory, } \\
\text { anti-influenza and sedative } \\
\text { actions. Recognised activity } \\
\text { against herpes simplex }\end{array}$ \\
\hline $\begin{array}{l}\text { Metropolitan area of } \\
\text { Belem, Brazil }\end{array}$ & $\begin{array}{c}\text { Erva-cidreira } \\
\text { (Wild Lemon Bush) } \\
\text { Lippia alba (Mill.) N.E. Br. ex } \\
\text { Britton and P. Wilson } \\
\text { VERBENACEAE }\end{array}$ & $\begin{array}{l}\text { Sedative, antispasmodic and } \\
\text { anticonvulsive activities. } \\
\text { Antibacterial, analgesic and } \\
\text { pectoral actions. }\end{array}$ \\
\hline S. Louis city, Brazil & $\begin{array}{c}\text { Erva-cidreira } \\
\text { (Wild Lemon Bush) } \\
\text { Lippia alba (Mill.) N.E. Br. ex } \\
\text { Britton and P. Wilson } \\
\text { VERBENACEAE }\end{array}$ & The same as Belem \\
\hline $\begin{array}{l}\text { Metropolitan area of } \\
\text { Havana, Cuba }\end{array}$ & $\begin{array}{c}\text { Tilo } \\
\text { Justicia pectoralis Jacq } \\
\text { ACANTHACEAE }\end{array}$ & $\begin{array}{l}\text { Sedative, anti-inflammatory and } \\
\text { antiseptic activity registered. }\end{array}$ \\
\hline $\begin{array}{l}\text { Metropolitan area of } \\
\text { San José, Costa Rica }\end{array}$ & $\begin{array}{c}\text { Manzanilla } \\
\text { (Chamomille) } \\
\text { Matricaria chamomilla } \mathrm{L} . \\
\text { ASTERACEAE }\end{array}$ & The same as in Lima \\
\hline $\begin{array}{l}\text { Rio Cuarto city, } \\
\text { Argentina }\end{array}$ & $\begin{array}{c}\text { Yerba Mate } \\
\text { (Mate Tea) } \\
\text { Ilex paraguariensis A. St.-Hil. } \\
\text { AQUIFOLIACEAE }\end{array}$ & $\begin{array}{c}\text { Digestive, strong stimulant, anti- } \\
\text { oxidant, diuretic, purgative, } \\
\text { vitamin (C), Alzheimer disease } \\
\text { prevention }\end{array}$ \\
\hline $\begin{array}{c}\text { Colonia del } \\
\text { Sacramento, Uruguay }\end{array}$ & $\begin{array}{c}\text { Yerba Mate } \\
\text { (Mate Tea) } \\
\text { Ilex paraguariensis A. St.-Hil. } \\
\text { AQUIFOLIACEAE }\end{array}$ & The same as Argentina \\
\hline
\end{tabular}

Source: Fieldwork data obtained during the 1998-2011 scientific missions.

Literature cited: [28-32]. 
Table 3: Medicinal plants origin in nine urban agglomerations of Latin America.

\begin{tabular}{|c|c|c|}
\hline Origin & Number of species & $\mathbf{( \% )}$ \\
\hline American & 343 & 61.2 \\
\hline European & 70 & 12.5 \\
\hline Asian & 63 & 11.3 \\
\hline African & 12 & 2.1 \\
\hline Pacific & 4 & 0.7 \\
\hline Australian & 7 & 1.3 \\
\hline Universal & 15 & 2.7 \\
\hline Unidentified & 46 & 8.2 \\
\hline Total & 560 & 100 \\
\hline
\end{tabular}

Source: Fieldwork data obtained during the 1998-2011 scientific missions.

Another interesting proof is the use of pharmaceutical drug names given to plants with similar use. It is the case with Vick (Mentha spicata), both in Belém and in S. Louis, because its smell resembles that of Vick's vapour rub, a widely available commercial product, as Prance and Plana also noticed in their study of "South American folk medicines" [24]. In our surveys several other examples were found, such as anador (Plectranthus barbatus), a commercial brand name for a Brazilian analgesic pill, and hepatalgina (Artemisia douglasiana) an hepatic South American Artemisia genus species [12, 13, 15].

Wild trees used to treat chronic diseases are quite abundant both in South and in Central America. The bark of Cinchona officinalis entered European pharmacopoeia by 1670's, becoming known in England as Peruvian bark. Nevertheless new and more effective methods of treating malaria are needed these days, because "the World Health Organization puts estimated cases of malaria for 2008 at 247 million, with nearly one million deaths occurring mostly among African children" [26]. Central American tree barks such as aceituno (Simarouba glauca), hombre grande (Quassia amara) and bushes like gavilana (Neurolaena lobata) have recognised anti-fever and anti-malarial properties. They are daily purchases in the central market of San Jose, Costa Rica [27]. Buddleja Americana, called tepozán in Mexico and yurac sacha in Peru, a Quechuan name, has proven activity against E. coli, anti-fever and anti-tumor properties [28]. It is traditionally used to treat venereal diseases, such as gonorrhea and syphilis [29].

The vast majority of the prescriptions use only one plant part. Research results presented a small number of mixed uses, particularly in the manufacture of anti-cough syrups: i) Brazilians add Indian clove to the leaf of local species, such as guava (Psidium guajava) and universal peppermint (Mentha x piperita); ii) Mexicans add several native flowers, for example tejocote (Crataegus mexicana), to gordolobo (Gnaphalium semiamplexicaule) and bougainville. Honey and, sometimes, lemon juice are common elements found in syrups' prescriptions. 


\section{Conclusions}

In times of crisis there is growing food insecurity and malnutrition [33]. The need to decrease national deficits is destroying most national healthcare systems worldwide. Consequently, urban agriculture is one of the responses that the urban poor find to meet their household needs. This fact, a clear regression in available wealth and a profound increase in the gap between rich and poor, in just one decade, explains why the number of medicinal species found within urban agglomerations has augmented.

In 1998, during the couple of scientific missions the IICT led to Belem, the author found ninety seven therapeutic species. In 2005, an additional market survey added forty-three, totalling one hundred and forty. By the end of 2010, another mission to $\mathrm{S}$. Louis accounted for one hundred and nine medicinal plants. In early 2011, the Portuguese-Argentinean team recorded a total of one hundred twenty-five species in the medium sized city of the pampas, Río Cuarto. By the end of 2011, seventy species were found in the tiny Uruguayan city of Colonia del Sacramento, the smallest researched so far. The preference for European herbs $(38.6 \%)$ was a surprising novelty.

In the Western world, nature is perceived as a collection of objects that can be manipulated through science [34]. Research results show that, with the exception of Uruguay, American plant species and ancient indigenous prescriptions dominate in consumption, particularly in Mexico (Aztecs and Nahua) and Peru (Aymara and Incas). These cultures traditionally used a variety of wild plant parts in infusions, inhalations and cataplasms. Herbal remedies are preferred by Latin-American low-income residents in case of influenza, diarrhea, stomach aches, malaria and venereal diseases, in Chile, Uruguay, Cuba, Peru, Mexico, Costa Rica and Brazil. Treatments use domestic prescriptions in Cuba and Argentina, where no ancestral practices were found. Most Argentineans buy or grow medicines against obesity, the main concern in the city of the pampas.

Data gathered in eight countries and nine urban agglomerations proved that the medicinal plants consumed are incredibly diverse. The five hundred and sixty species belong to a total of one hundred and three different families. Urban gardeners prefer to grow Asteraceae, Lamiaceae, Malvaceae, Rosaceae, Verbenaceae and Euphorbiaceae. Regarding fruit trees, Rutaceae are the most common. Tropical tree barks are also quite diverse but Fabaceae are by far the most used; Simaroubaceae and Lauraceae follow. The world financial crisis challenges urban residents into finding new ways to deal with scarcity. Individual genius and household resilience are new driving forces for change that defy inertia and failure of so many elected governments worldwide.

\section{References}

[1] Whitehead, M. (Re)Analysing the sustainable city: nature, urbanism and the regulation of socio-environmental relations in the UK. Urban Studies. 40 (7). pp. 1183-1206, 2003. 
[2] Dadush, U. and Shaw, W. Juggernaut. How emerging markets are reshaping globalization. Carnegie Endowment for Peace: Washington, 2011.

[3] Williams, K. Sustainable Cities: research and practice challenges. Journal of Sustainable Development. 1 (1-2). pp. 128-132, 2010.

[4] Weller, R. Boomtown 2050:scenarios for a rapidly growing city. University of Western Australia Publishing: Perth, 2009.

[5] Madaleno, I.M. Climate Change in the Pacific - Tuvalu case-study. Ecosystems and Sustainable Development. Ed. Villacampa, Y and C.A. Brebbia, Southampton: Wit Press. pp. 243-252, 2011.

[6] Paynter, P. Planning Sustainable Cities, Global Report on Human Settlements 2009. Australian Planner. 48 (3). pp. 243-244, 2011.

[7] Sassen, S. The City: Its return as a lens for social theory. City, Culture and Society. 1. pp. 3-11, 2010.

[8] Seale C. Social Research Methods, a Reader. Routledge: London, 2004.

[9] Collier, J. Jr. and Collier, M. Principles of Visual Research. Social Research Methods, a Reader. Ed. C. Seale. Routledge: New York. pp. 279, 2004.

[10] Smith, N. Uneven Development. Nature, Capital and the Production of Space. The University of Georgia Press: Athens, 2008.

[11] Sage, C. Environment and Food. Routledge: Abingdon, 2011.

[12] Madaleno, I.M. Urban Agriculture in Belém, Brazil. Cities. 17 (1). pp. 73 77, 2000.

[13] Madaleno, I.M. Urban Agriculture in Brazil. A tale of two cities. Trialog.65 (2). pp. 24-27, 2000.

[14] Castro Henriques, J. Urban agriculture and resilience in Lisbon: The role of the municipal government. Urban Agriculture Magazine. 22. pp. 49-50, 2009.

[15] Madaleno, I.M. A Comparative Study of Medicinal Plant Cultivation and Uses in Six Latin American Cities. Advances in Environmental Biology. 5(2). pp. 307-314, 2011.

[16] Santandreu, A. Perazzoli, A. G. Terrile, R. Ponce, M. Urban agriculture in Montevideo and Rosário: A response to crisis or a stable component of the urban landscape? Urban Agriculture Magazine. 22. pp. 12-13, 2009.

[17] Dubbeling, M. Campbell, M.C., Hoekstra, F. and Veenhuizen, R van. Building resilient cities. Urban Agriculture Magazine. 22. pp. 3-11, 2009.

[18] Santandreu, A. Perazzoli, A. G. Terrile, R. Ponce, M. Urban agriculture in Montevideo and Rosário: A response to crisis or a stable component of the urban landscape? Urban Agriculture Magazine, 22. pp. 12-13, 2009.

[19] Benavente, M. D. El empresariado nacional. Hacia un capitalismo colaborativo. Ed. R. Arocena and G. Caetano La Aventura Uruguaya. Editorial Sudamericana Uruguaya: Montevideo. pp. 91-110, 2011.

[20] Madaleno, I.M. and Montero, M.C. El Cultivo de Plantas Medicinales, su Comercialización y Usos Fitoterapéuticos en Argentina: Estudio de Caso La Ciudad de Río Cuarto, Córdoba, Argentina. Anales VIII Coloquio de Desarrollo Local. Baeza, Spain, 28-30 June, 1-15, 2011. 
[21] Bailkey, M. An update from New Orleans. Urban Agriculture Magazine. 22. pp. 17-19, 2009.

[22] De Zeeuw, H. RUAF 10 years: Achievements and Challenges. Urban Agriculture Magazine. 25. pp. 3-7, 2011.

[23] Madaleno, I.M. and Gurovich, A. "Urban Versus Rural" no Longer Matches Reality: endurance of an early public agro-residential development in peri-urban Santiago, Chile. Cities. 21 (6). pp. 513-526, 2004.

[24] Prance, G. T. and Plana, V. The use of alien plants in tropical South American folk medicines. Plants for food and medicine. Ed. H. D. V. Prendergast, N. L. Etkin, D.R. Harris and P. J. Houghton. Royal Botanic Gardens, Kew, pp. 185-200. 1998.

[25] Madaleno, I.M. Traditional Medicinal Knowledge in Cuba. Island Sustainability. Ed. S. Favro and C. A. Brebbia, C.A. Wit Press: Southampton. pp. 101-110, 2010.

[26] Payne, M. Marianne North, a very intrepid painter. Royal Botanic Garden, Kew, 2011.

[27] Madaleno, I.M. Traditional Medicinal Knowledge in Costa Rica. Conference on International Agricultural Research for Development. ETH Zurich: Zurich: pp. 1-4, 2010. http://www.tropentag.de/2010/abstracts/ full/542.pdf

[28] Navas, H.R. 2007. La Utilidad de las Plantas Medicinales de Costa Rica. Euna: Heredia, 2007.

[29] Agapito, T. and Sung, I. Fitomedicina I and II. Editora Isabel: Lima, 2004.

[30] Alonso, C. M, Ochoa, F. L, Rodriguez, B. E and Essayag, R. M. Plantas Medicinales en México II: composición, usos y actividad biológica. UNAM: México, 1999.

[31] WHO. WHO Monographs on selected medicinal plants. World Health Organisation: Geneva, 2007.

[32] Missouri Botanical Garden. Plant Taxonomy. Accessed the $6^{\text {th }}$ March 2012 $<$ www.tropicos.org $>$

[33] Cofie, O., Veenhuizen, R. van, Vreede, V. de, Maessen, S. Waste Management for Nutrient Recovery: Options and Challenges for Urban Agriculture. Urban Agriculture Magazine. 23. pp. 3-7, 2010.

[34] Warkentin, T. Cultivating urban naturalists: Teaching experiential, placebased learning through nature journaling in Central Park. Journal of Geography. 110 (6). pp. 227-238, 2011. 